Article

\title{
Agricultural Oasis Expansion and Its Impact on Oasis Landscape Patterns in the Southern Margin of Tarim Basin, Northwest China
}

\author{
Yi Liu ${ }^{1,2,3,4}$, Jie Xue ${ }^{4,5, *}$, Dongwei Gui ${ }^{4,5, *}$, Jiaqiang Lei ${ }^{4,5}$, Huaiwei Sun ${ }^{6}{ }^{(\mathbb{C})}$, Guanghui Lv ${ }^{1,2}$ \\ and Zhiwei Zhang ${ }^{7}$ \\ 1 Institute of Arid Ecology and Environment, Xinjiang University, Urumqi 830046, China; \\ yiliu319@126.com (Y.L.); ler@xju.edu.cn (G.L.) \\ 2 Key Laboratory of Oasis Ecology, Xinjiang University, Urumqi 830046, China \\ 3 University of Chinese Academy of Sciences, Beijing 100049, China \\ 4 State Key Laboratory of Desert and Oasis Ecology, Xinjiang Institute of Ecology and Geography, \\ Chinese Academy of Sciences, Urumqi 830011, China; desert@ms.xjb.ac.cn \\ 5 Cele National Station of Observation and Research for Desert-Grassland Ecosystems, Cele 848300, China \\ 6 School of Hydropower and Information Engineering, Huazhong University of Science and Technology, \\ Wuhan 430074, China; huaiweisun@whu.edu.cn \\ 7 Xizang Agriculture and Animal Husbandey College, Tibet University, Lhasa 850000, China; \\ aiwoweige@163.com \\ * Correspondence: xuejie11@mails.ucas.ac.cn (J.X.); guidwei@ms.xjb.ac.cn (D.G.); \\ Tel.: +86-0991-7885-317 (J.X. \& D.G.)
}

Received: 20 April 2018; Accepted: 5 June 2018; Published: 11 June 2018

\begin{abstract}
Oasis landscape change and its pattern dynamics are considered one of the vital research areas on global land use and landscape change in arid regions. An agricultural oasis is the main site of food security and ecosystem services in arid areas. Recently, the dramatic exploitation of agricultural oases has affected oasis stability, inducing some ecological and environmental issues such as water shortage and land degradation. In this study, the Qira oasis on the southern margin of Tarim Basin, Northwest China, was selected as a study area to examine the spatiotemporal changes in an agricultural oasis and the influence on oasis landscape pattern. Based on the integration of Thematic Mapper, Enhanced Thematic Mapper Plus, and GF-1 images, the agricultural Qira oasis has rapidly increased, with annual change rates of $-0.3 \%, 1.6 \%, 3.7 \%$, and $1.5 \%$ during 1970-1990, 1990-2000, 2000-2013, and 2013-2016, respectively. With the agricultural oasis expansion, the agricultural land has increased from $91.10 \mathrm{~km}^{2}$ in 1970 to $105.04 \mathrm{~km}^{2}$ in 2016 . The percentage of farmland area has increased by $15.3 \%$ in 2016 compared with that in 1970. The natural vegetation is decreasing owing to the reclamation of desert-oasis ecotone. The oasis landscape change and pattern are mainly affected by agricultural expansion under water-saving technological utilization, land use policy, and regional economic development demand. The expansion of agricultural oasis is alarming due to human overexploitation. Thus, the government should adjust the layout of agricultural development and pay considerable attention to the oasis environment sustainability. This study can provide a valuable reference on the impact of climate change and human activities on a landscape.
\end{abstract}

Keywords: oasis; landscape change; agricultural oasis expansion; Tarim Basin

\section{Introduction}

The landscape is shaped by a combination of natural and anthropogenic factors [1,2]. Landscape change and its dynamics are one of the major research areas in global environmental variation 
and landscape ecology [3-7]. Recently, landscape change has received worldwide concern from different perspectives including the context, direction, rate, and spatiotemporal variation $[6,8]$. In arid or semiarid regions, the oasis as a unique landscape coexists with deserts like the Gobi, allowing vegetation to flourish and humans to thrive due to the presence of runoff, spring water, and groundwater [9-11]. The oasis is the basis of human settlement and economic development; it supports more than $95 \%$ of the population and more than $90 \%$ of social wealth, with only $5-6 \%$ of the land surface in arid and semiarid regions of China [6,12]. Therefore, research on oasis change or dynamics has become a key topic for sustainability $[10,13]$.

According to its formation mechanism, oases are classified into natural or artificial types [14]. Natural oases include shrubby grassland, water bodies, and desert areas. Artificial oases contain agricultural oases, shelter forests, and residential areas [12,14,15]. In recent decades, there has been a significant expansion of oasis land, particularly agricultural oasis, in the arid regions of Northwest China [16]. An agricultural oasis refers to cultivated land irrigated by human activities, and provides food security [10]. With the expansion of agricultural oasis to increase grain yields, the scale of agricultural oasis is limited by the availability of irrigation water in arid regions [17]. If agricultural oasis expansion exceeds the water carrying capacity, the natural landscape will be threatened, resulting in a series of environmental issues [17,18]. Therefore, the dynamics of agricultural oasis landscape patterns need to be analyzed to determine the sustainable scale.

Previous studies on oasis change mainly focused on land use and vegetation change in desert oasis areas $[2,15,19,20]$, the ecological effects and the suitable scale of agricultural oasis [17,21,22], the relationship between the oasis dynamics and water resources [14,23], and the patterns and reasons of agricultural oasis expansion [10]. These studies analyzed the changes and dynamics of oasis landscapes in arid and semiarid regions. However, less attention has been given to identifying the trends and driving forces of agricultural oasis and their impact on oasis landscape patterns through qualitative and quantitative analyses.

To systematically understand the expansion dynamics of agricultural oasis and its impact on oasis landscape patterns, this study selected the Qira oasis, a typical natural and agricultural oasis on the southern margin of Tarim Basin, Northwest China, as a study area to examine agricultural oasis change and its impact on landscape patterns using multisource satellite images. The main objectives of this study are to (1) detect the spatiotemporal changes of agricultural oasis in the Qira oasis from 1970 to 2016; (2) characterize the trends of agricultural oasis and analyze its influence on oasis landscape patterns; (3) identify the direction and driving factors of oasis landscape change; and (4) discuss feasible recommendations for agricultural oasis sustainability.

\section{Study Area}

The Qira oasis is located within the central part of the southern Taklamakan Desert and the northern foot plain of the Kunlun Mountains $\left(80^{\circ} 43^{\prime} \mathrm{E}-80^{\circ} 53^{\prime} \mathrm{E}, 36^{\circ} 57^{\prime} \mathrm{N}-37^{\circ} 05^{\prime} \mathrm{N}\right)$, covering an area of approximately $157 \mathrm{~km}^{2}$ (Figure 1). It is a typical alluvial fan, in which the agricultural and natural oases are the main landscape units [24,25]. The water supply in the Qira oasis area depends mainly on Qira river runoff, which comes from a high-altitude valley of the Kunlun Mountains, flowing through the Qira oasis, and finally discharging into the extremely arid Taklimakan desert $[24,25]$. Its annual runoff was $1.27 \times 10^{8} \mathrm{~m}^{3}$ during 1985-2010. The climate is hyperarid with an average annual temperature of $11.9^{\circ} \mathrm{C}$, annual precipitation of $35 \mathrm{~mm}$, and annual potential evaporation of $2600 \mathrm{~mm}$ [26]. The soil is mainly classified as aeolian sandy soil. The oasis has a soil moisture content of $0.15-0.35 \%$ on the surface at a depth of $0-20 \mathrm{~cm}$ [27]. The farmland is the main land use type, with wheat, maize, and cotton being the main crops. The desert-oasis ecotone with $20-40 \%$ vegetation coverage is distributed in the northwestern edge of the Qira oasis [28]. The key vegetation types contain Tamarix chinensis, Calligonum, and Alhagi sparsifolia. In recent decades, with the expansion of the agricultural oasis, the landscape patterns have changed significantly, creating a large number of 
ecological and environmental issues. Therefore, research on the dynamics of agricultural oasis and landscape patterns in the Qira oasis is crucial for better-informed landscape management decisions.
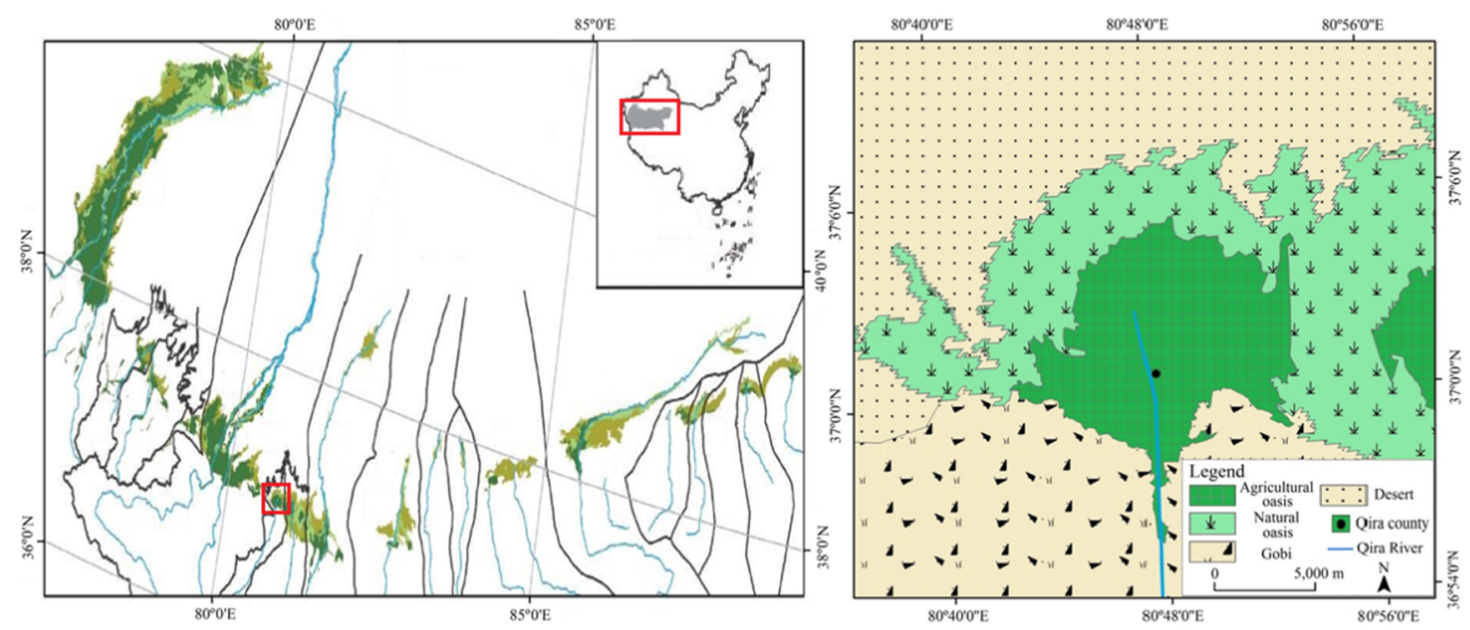

Figure 1. Location of Qira oasis in the southern Tarim Basin (adapted from [24]).

\section{Materials and Methods}

\subsection{Data Sources}

In this study, the data used to examine agricultural oasis expansion and landscape dynamics in the Qira oasis were based on five time periods of images. Land use images of the Xinjiang Uyghur Autonomous Region in 1970 with a scale of 1:50,000 were provided by the Surveying and Mapping Bureau of Xinjiang Uyghur Autonomous Region. Landsat Thematic Mapper (TM) and Enhanced Thematic Mapper Plus (ETM+) provided images in 1990 and 2000 with $30 \times 30$ m nominal resolution. The images in 2013 and 2016 were acquired GF-1 satellite. The scale of the images was 1:100,000. The images in summer or autumn were selected to determine vegetation phenology [7]. The TM, ETM+, and GF-1 images were interpreted by a human-machine interactive approach [10]. The land use/cover in the oasis landscape was divided into six types, including farmland, water area, residential area, shrubby grassland, forestry area, and desert area with low vegetation cover $(<5 \%)$ (Table 1$)$. The mean interpretative accuracy of the land use/cover images was greater than the kappa coefficient of $95 \%[29,30]$.

Table 1. Explanation for the landscape units in the Qira oasis.

\begin{tabular}{cl}
\hline Landscape Type & \multicolumn{1}{c}{ Explanation } \\
\hline Farmland & Agricultural area including annual crops, crop residues, vegetables, and bare soils \\
\hline Water area & Entity water including rivers, lakes, reservoirs, and wetland \\
\hline Residential area & Built-up area including buildings and facilities \\
\hline Shrubby grassland & $\begin{array}{l}\text { High-coverage shrubby grassland with vegetation cover }>60 \% \text {, medium-coverage } \\
\text { shrubby grassland with vegetation cover of 20-60\%, and low-coverage shrubby } \\
\text { grassland with vegetation cover of 5-20\% }\end{array}$ \\
\hline Forestry area & Shelter forest for protecting farmland from aeolian sand disaster \\
\hline Desert area & Sandy land with vegetation cover $<5 \%$, barren rock, and Gobi \\
\hline
\end{tabular}

To analyze the impacts of the climate change and socioeconomic factors on agricultural oasis expansion and landscape dynamics, the meteorological (i.e., temperature and precipitation) and hydrological data in 1958-2010 were collected from the Qira meteorological station and Qira 
hydrological station, respectively. The socioeconomic data including population, gross domestic product, income, irrigation, and crop yields were acquired from the Xinjiang Statistical Yearbook (2000-2013) on the Qira county level. These data were used as ancillary data to interpret the main reason, driving forces, and trend of oasis landscape change in the Qira study area.

\subsection{Detection Methods of the Oasis Landscape Changes}

The satellite images interpreted are generated by the five resulting maps in 1970, 1990, 2000, 2013, and 2016 using GIS. These images can identify the change occurrence and temporal trajectories of land cover types. Variation in land use types is one of the main indicators for showing the landscape change and dynamics. Oasis landscape change can be described by the annual change rate $(R)$ for each oasis land cover types [31], which was calculated as follows:

$$
R=\left(\sqrt[t_{2}-t_{1}]{A_{2} / A_{1}}-1\right) \times 100 \%
$$

where $A_{1}$ and $A_{2}$ refer to the land-use area for each land cover types of Qira oasis based on the satellite images interpreted at the initial and last stages of a time period, respectively, and $t_{2}-t_{1}$ represents the time length of the initial and last stage period.

In addition, the analysis of oasis landscape pattern can be characterized by the average annual transition probabilities $(P)$ between the agricultural oasis and other landscape units, which was calculated as follows [7]:

$$
P=\frac{A_{i j}}{T} / \sum_{j} A_{i j} \times 100 \%
$$

where $A_{i j}$ is the area of land use type $i$ of Qira oasis from the initial period to the last stage $j$ in a time period and $T$ is the number of years from the initial period to the last stage.

\section{Results}

\subsection{Oasis Landscape Change and Agricultural Oasis Expansion}

Figures 2 and 3 show the oasis landscape change from 1970 to 2016. The Qira oasis area decreases slightly at an annual rate of $-0.69 \%$ in 1970-1990, but has increased rapidly with annual change rates of $0.48 \%, 0.95 \%$, and $0.08 \%$ during $1990-2000,2000-2013$, and 2013-2016, respectively. For the entire period of 1970-2016, the Qira oasis first shrank (1970-1990) and then gradually sprawled (1990-2016). By contrast, the desert area increased significantly from $214.55 \mathrm{~km}^{2}$ in 1970 to $260.33 \mathrm{~km}^{2}$ in 1990, but the area dramatically decreased by $21.86 \%$ from $260.33 \mathrm{~km}^{2}$ in 1990 to $149.42 \mathrm{~km}^{2}$ in 2016 (Figure 4). The speed of oasis expansion is faster than that of land desertification. 

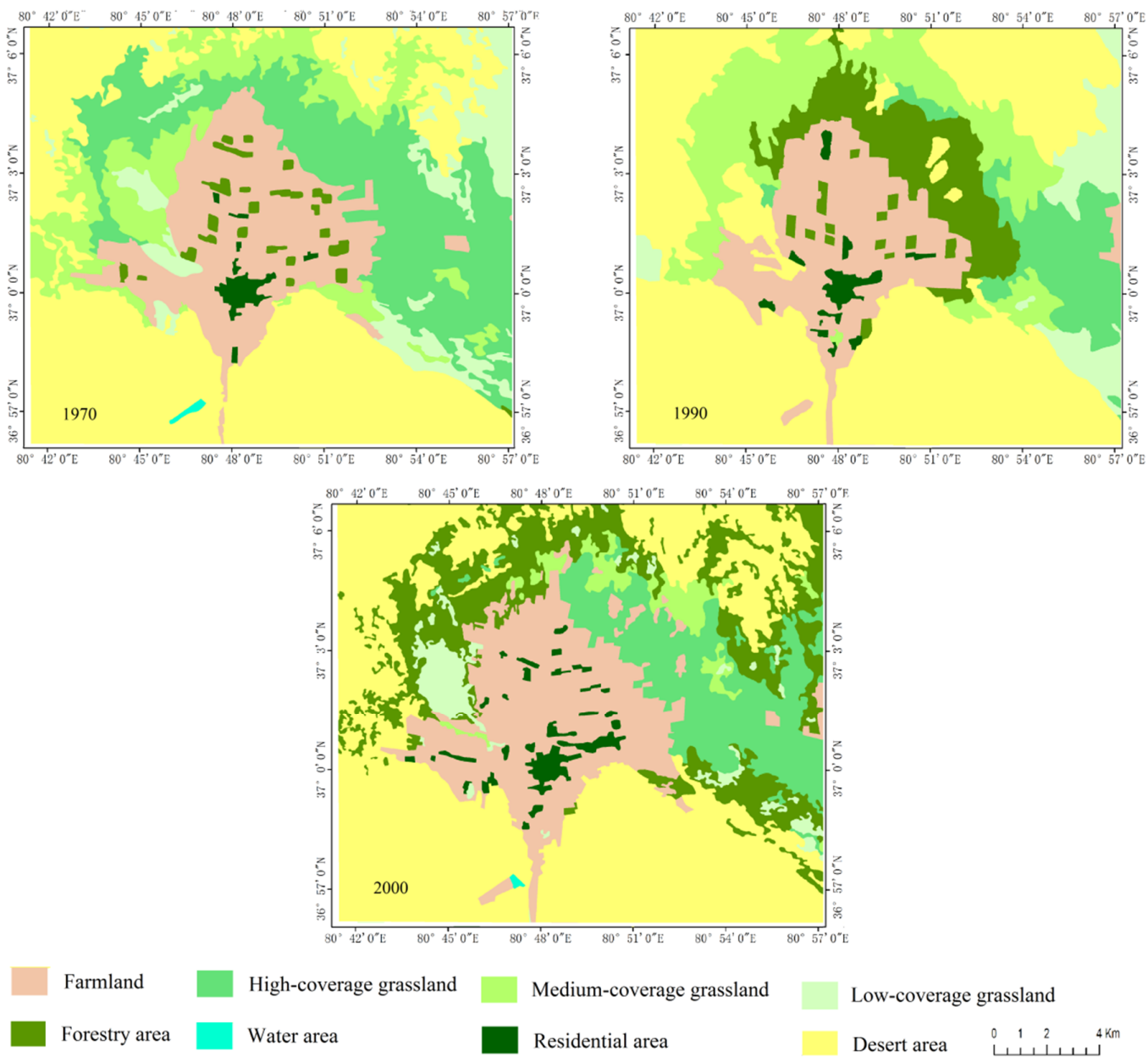

Figure 2. Landscape pattern and agricultural oasis expansion in the Qira oasis from 1970 to 2000.
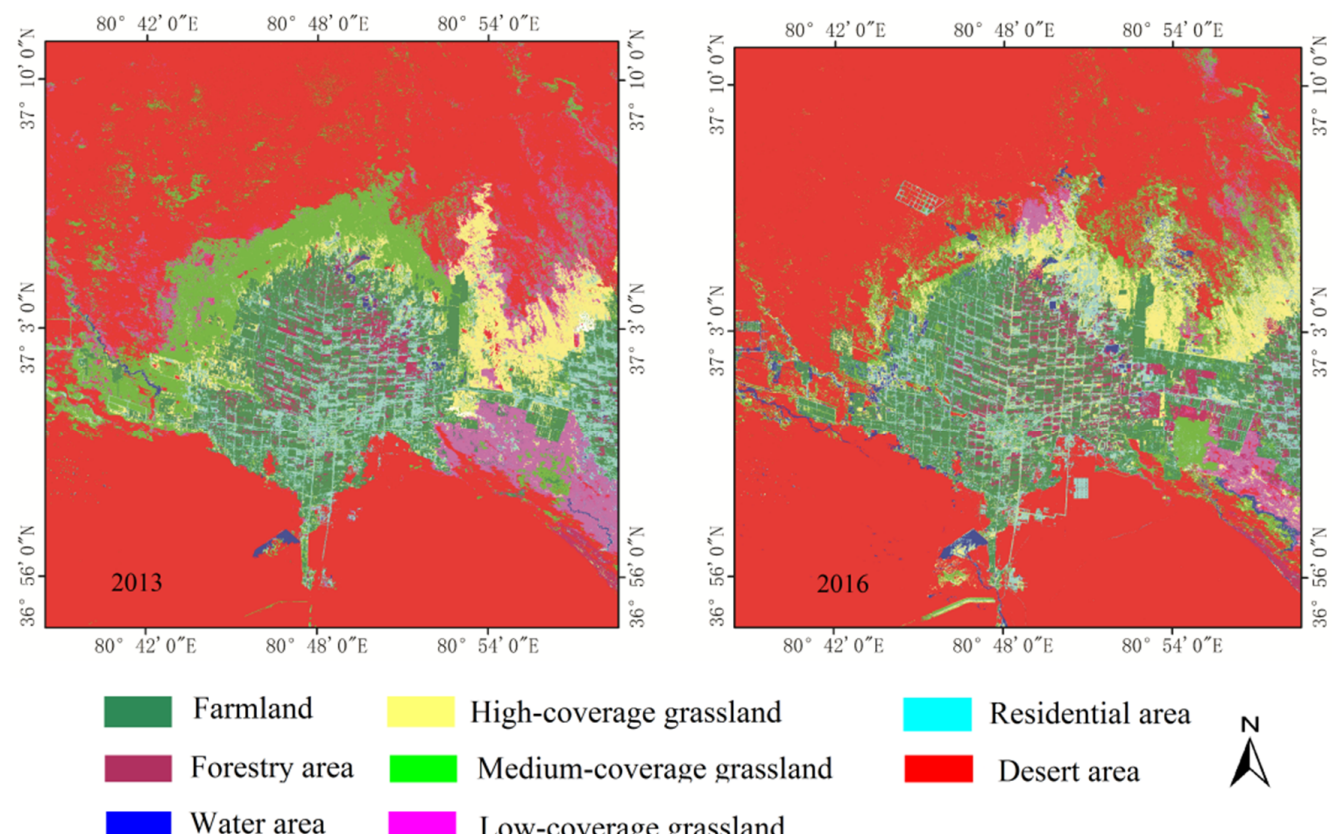

High-coverage grassland

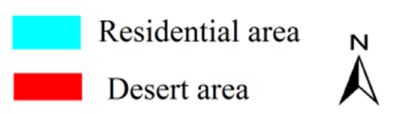

Water area

Medium-coverage grassland

Low-coverage grassland

Figure 3. Landscape pattern and agricultural oasis expansion in the Qira oasis from 2013 to 2016. 


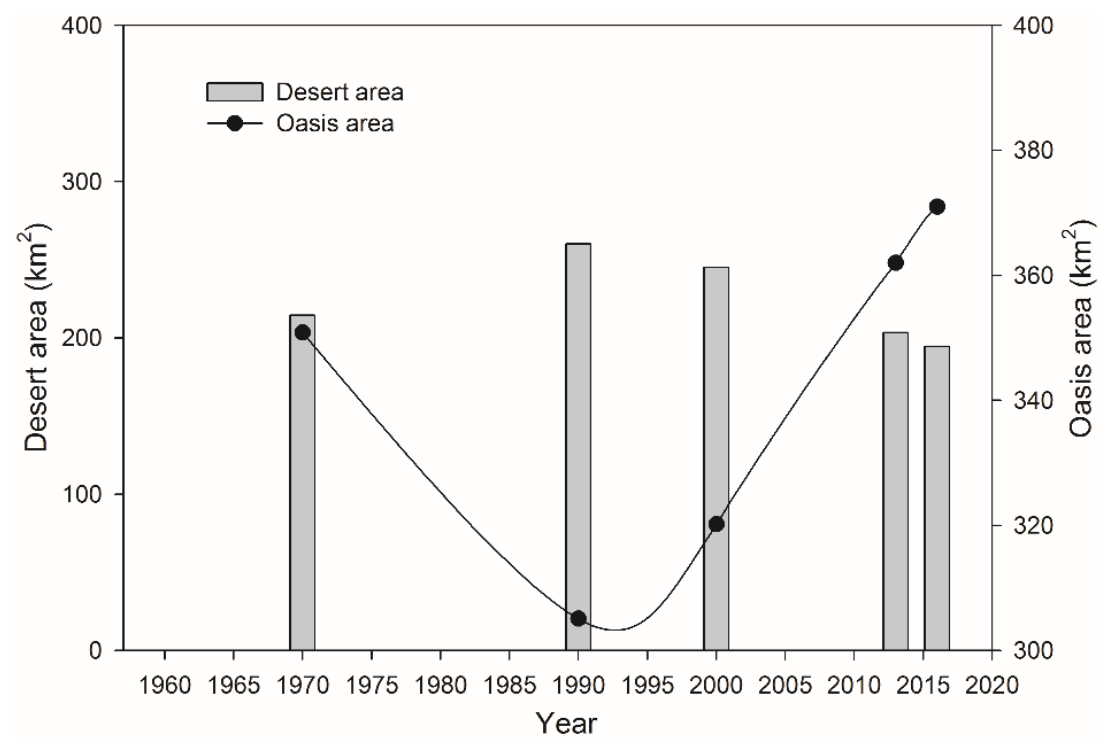

Figure 4. Changes of desert and oasis landscapes during 1970-2016.

In the oasis landscape units, the most significant change in the Qira oasis belongs to the agricultural oasis expansion. The agricultural oasis rapidly increases with annual change rates of $-0.3 \%, 1.6 \%, 3.7 \%$, and $1.5 \%$ during 1970-1990, 1990-2000, 2000-2013, and 2013-2016, respectively. With the expansion of agricultural oasis, the agricultural land has increased from $91.10 \mathrm{~km}^{2}$ in 1970 to $105.04 \mathrm{~km}^{2}$ in 2016. The percentage of farmland area has increased by $15.3 \%$ since 1970 (Figure 5a). In the spatial variation, the agricultural oasis expansion mainly extends toward the northwest of the oasis during 1970-2000, whereas the farmland expansion from 2000 to 2016 was in the northwest and northeast directions.
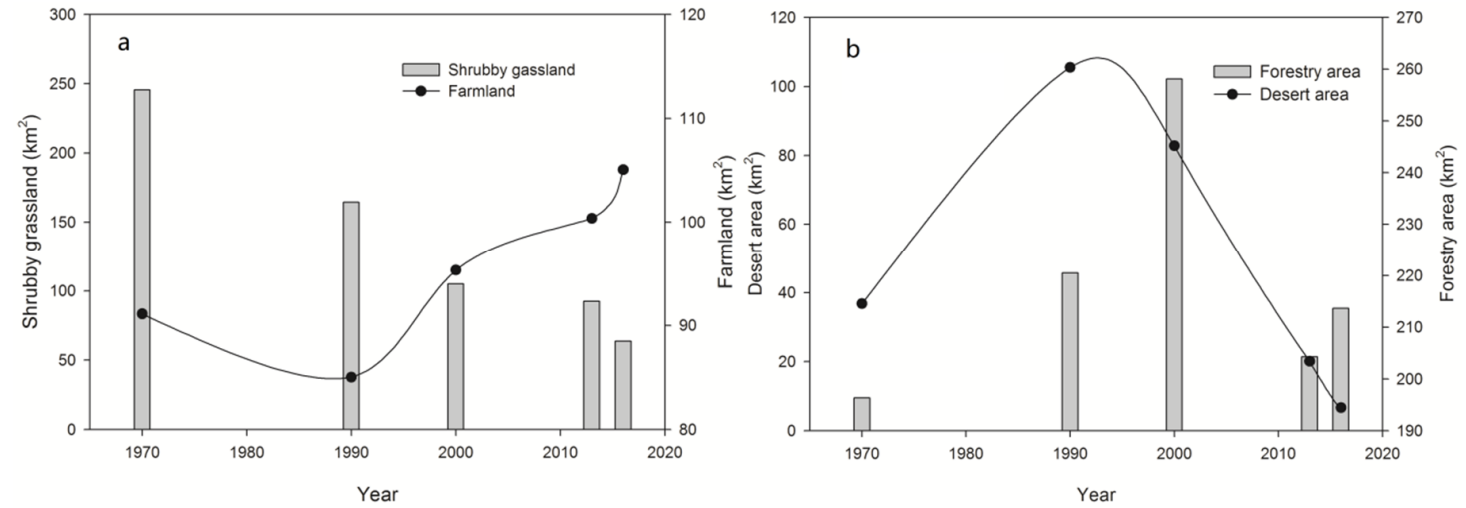

Figure 5. Land-use changes in the Qira oasis during 1970-2016: (a) farmland area and shrubby grassland area; (b) forestry area and desert area.

\subsection{Response of Oasis Land Cover Pattern to the Agricultural Oasis Expansion}

As the most important natural vegetation for wind prevention and sand resistance, shrubby grassland has rapidly declined with annual change rates of $-1.98 \%,-4.37 \%,-2.85 \%$, and $11.60 \%$ in 1970-1990, 1990-2000, 2000-2013, and 2013-2016, respectively. Compared with that in 1970, the shrubby grassland area in the Qira oasis has decreased by 74.01\% in 2016 (Figure 5a). In addition, the forestry area has rapidly increased with annual change rates of $8.15 \%$ and $8.36 \%$ in $1970-1990$ and $1990-2000$, respectively. However, the forestry area significantly decreased with annual change rate of $-6.08 \%$ from 2000 to 2016 (Figure 5b). In 2016, the forestry area has drastically declined owing to agricultural reclamation and overexploitation. 
In terms of the oasis land cover change, there is no significant variation in water areas and built-up areas in the Qira oasis. The expansion of agricultural oasis has impacted the change of the oasis landscape pattern. The average annual transition probability from desert to agricultural oasis has increased by $26.82 \%$, that from shrubby grassland to agricultural oasis by $38.04 \%$, and that from forestland to agricultural oasis by $35.13 \%$. Thus, the natural vegetation is partly lost to agricultural expansion and occupation. The protective function of natural vegetation against desertification and soil degradation may be weakened. With respect to the decrease of natural vegetation, such a trend is alarming for the sustainable development of the Qira oasis in the future.

\subsection{Driving Force Analysis of Oasis Landscape Pattern under Agricultural Oasis Expansion}

In the Qira oasis area, the natural condition, anthropogenic activities, and human factors, such as population, food security demand, water resource availability, and land use policy, are affecting the oasis landscape change $[7,8,10]$.

The annual mean temperature and precipitation are affirmed with obvious positive impacts on the agricultural oasis expansion at significance level $p<0.01$ using the panel data model [10]. Figure 6 shows the change of annual mean temperature and precipitation in the Qira oasis study area. These two meteorological parameters illustrate an increasing trend. The increase in temperature benefits cotton plantations, while the increase in precipitation increases the possibility of crop planting. Thus, these natural conditions can induce the reclamation of agricultural oasis.

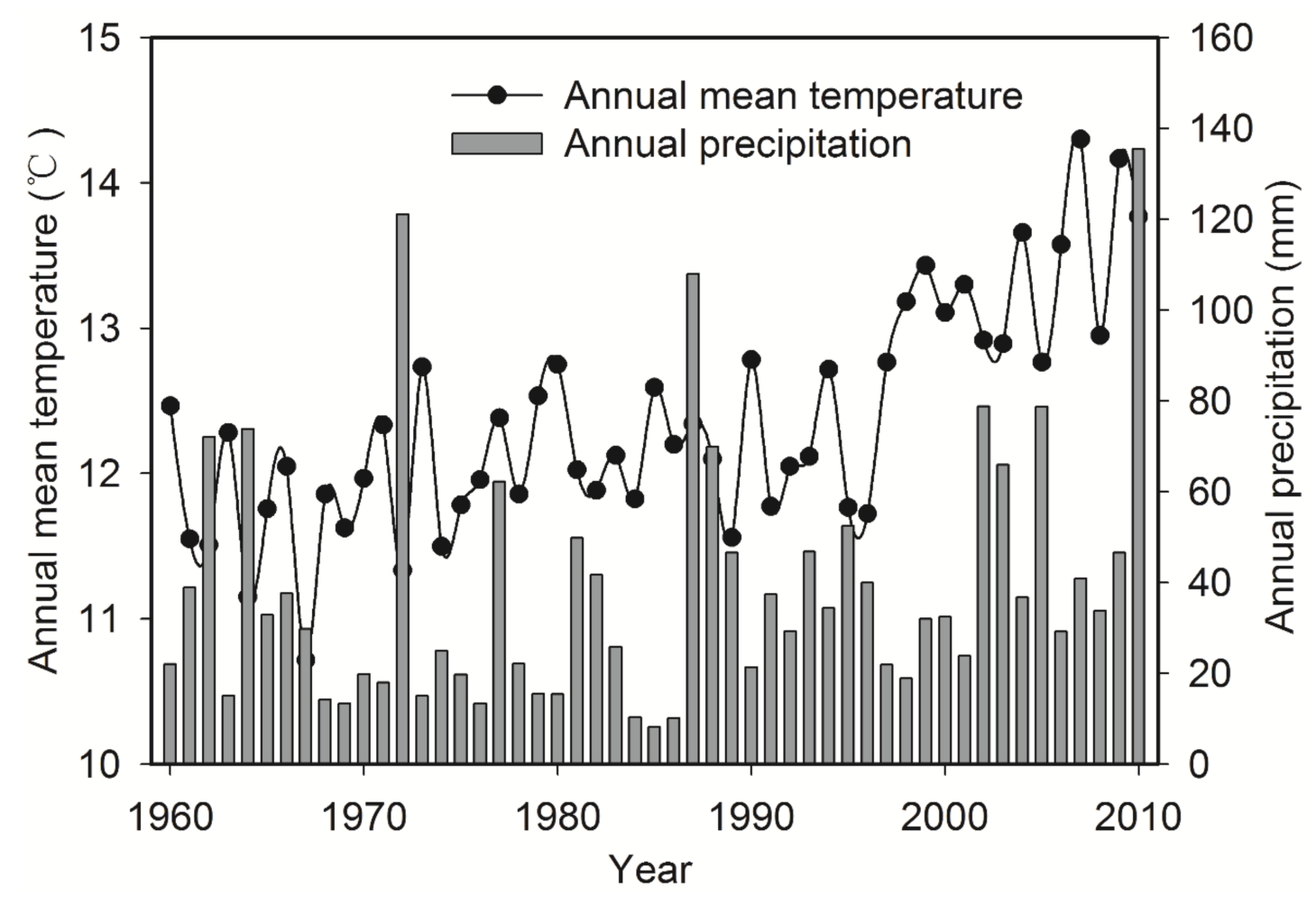

Figure 6. Annual mean temperature and precipitation in the Qira oasis.

The continuous increase in human population is considered as the main factor in agricultural oasis expansion [32,33]. The population in this area has increased from 24,100 in 1955, to 44,900 in 1990, to 55,568 in 2010 (Figure 7). Compared with 1990, the population in 2010 has increased by $23.76 \%$. The continuous growth in human population will inevitably lead to an increase in arable land to support grain yield (Figure 7). Therefore, new agricultural oasis reclamation is needed for human survival at the expense of the natural ecosystem. 


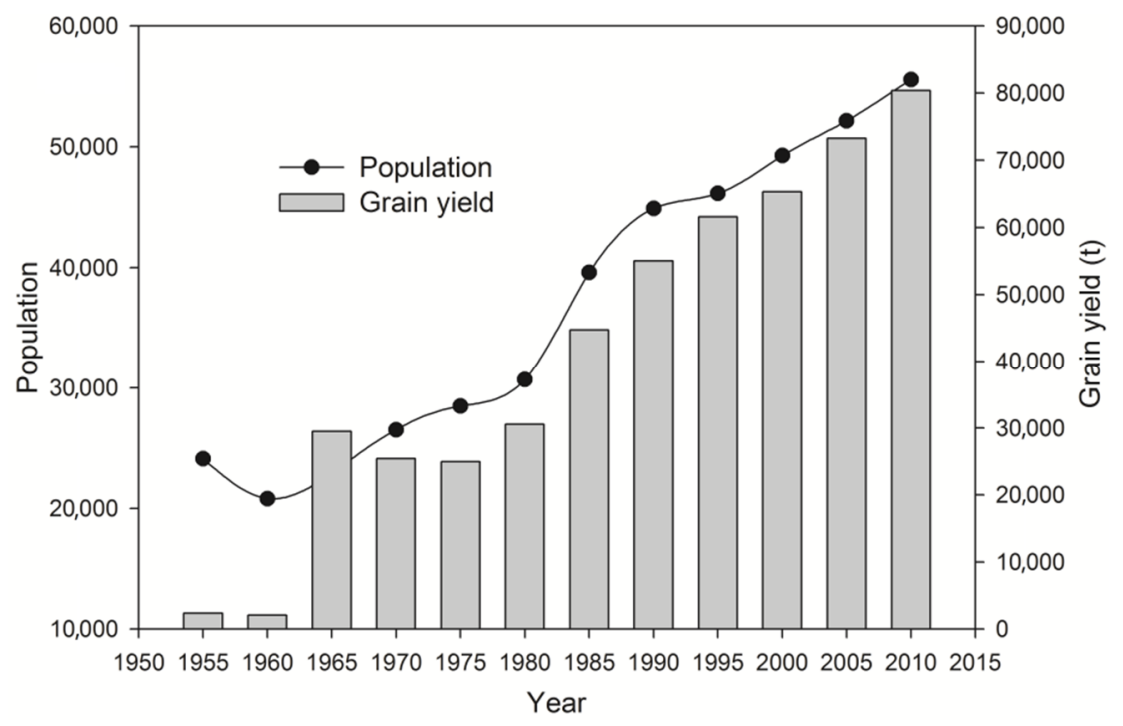

Figure 7. Population and grain yield in the Qira oasis.

The limited water resources directly determine the scale of the oasis expansion $[17,19]$. The water availability in the Qira oasis area mainly relies on Qira River discharge due to strong evaporation (2700 mm/year) and highly vulnerable ecosystems [2]. Approximately $97.7 \%$ of the total water consumption is used to meet irrigation needs. Moreover, $82.1 \%$ of the irrigation for agriculture comes from the Qira River, while $17.9 \%$ of the remaining water is extracted from groundwater [33]. According to the hydrological data from 1960 to 2010, the runoff in Qira River declined at a rate of $0.003 \times 10^{8} \mathrm{~m}^{3} /$ year (Figure 8). This makes it difficult to support new agricultural oasis expansion and threatens the sustainability of the Qira oasis. However, water-saving methods, such as the application of drip irrigation technology and improvement of agricultural mechanization level, can improve the expansion of Qira agriculture oasis with less irrigation needed.

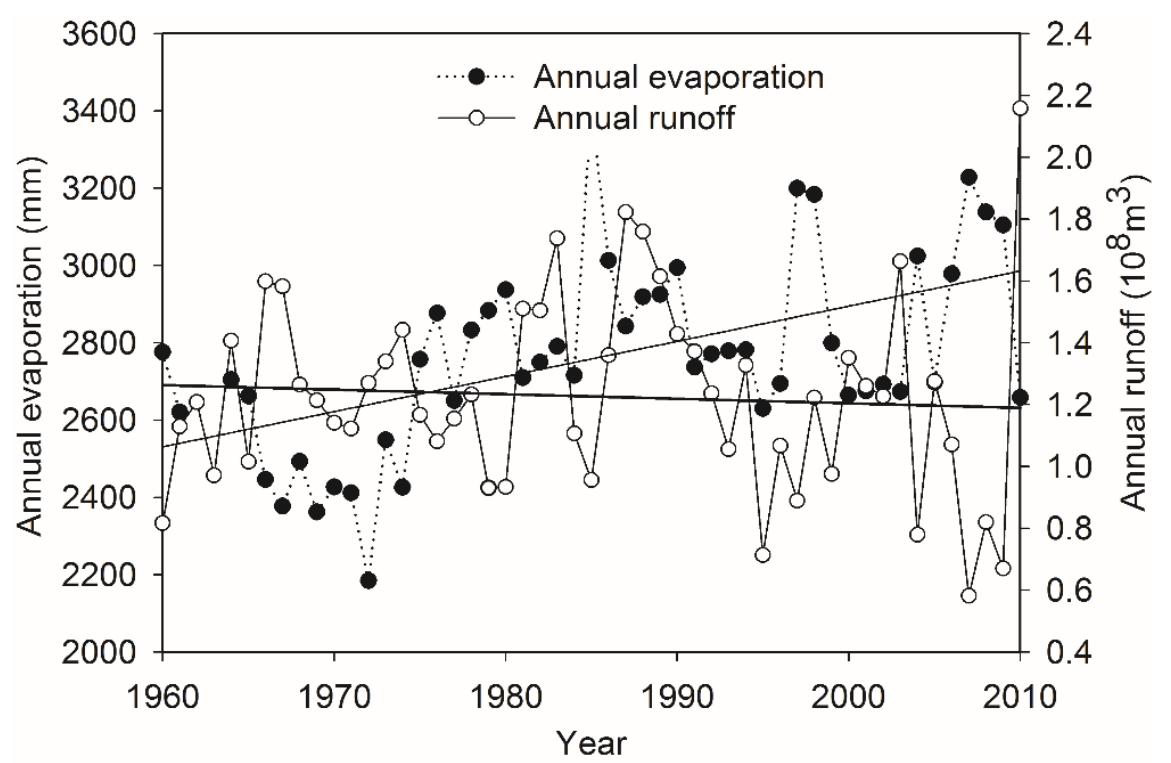

Figure 8. Annual evaporation and runoff in the Qira oasis.

The policy of opening up wasteland has played a key role in the Qira oasis sustainability [34]. Land reclamation is an alternative way to obtain abundant food and income due to poor living conditions. In addition, new reservoirs have been built in the upper reaches of the Qira River for 
agricultural irrigation. A decreasing groundwater table in the frontier area of Qira oasis leads to the die-off of natural vegetation (such as grassland and desert shrub) at the oasis landscape level [2]. However, the natural vegetation of the oasis, especially the desert-oasis ecotone as an important site for ecosystem services, is important in order to protect the ecotone biodiversity against excessive wasteland reclamation and abusive levels of grazing [35].

\section{Discussion}

This study shows that the Qira oasis landscape has changed significantly during 1970-2016. The increase in agricultural oasis profoundly impacts its landscape pattern and stability. The dynamics of agricultural oasis is the most important cause of oasis landscape change [8]. Given the human activities and climate change, the size and scale of the Qira oasis is highly dynamic under agricultural oasis expansion. This finding is similar to previous research in other oases, such as the Jinta [8] and Hotan oases [7], in which it was reported that human activities and climate changes have significantly changed the water resource distribution, leading to a rapid expansion of agricultural oasis.

The relationship between agricultural oasis change and its landscape pattern is very complex. In arid and semiarid regions, there is still no consensus to reasonably interpret the oasis landscape change and its driving forces at a regional level $[8,36,37]$. Furthermore, considering the influence of climate change and human activities, it is difficult to determine the influence of agricultural oasis expansion on the oasis landscape [10]. Song and Zhang [10] found that the precipitation and temperature drives the agricultural oasis expansion in the Heihe River Basin of China, while Fu [38] reported that human activities mostly accounted for the rapid expansion of agricultural oasis. However, this study shows that socioeconomic factors such as population increase, technological advancements in water resource utilization for surface water exploitation and groundwater pumping [7], economic development, and land use policy in opening up wastelands are responsible for the expansion of the Qira agriculture oasis. The results are basically consistent with the work of Zhou [39], who points out that rapid agricultural and economic development lead to expansion of agricultural oasis through occupying the oasis-desert ecotone.

While agricultural oasis expansion is necessary for ensuring food security, it significantly decreases the proportion of natural grasslands and forestlands. The implication for ecological and environmental development of the Qira oasis is alarming. The decline in grassland and forestland due to farmland reclamation will lead to desertification risks. Once destroyed, natural vegetation is difficult to re-establish [2]. Therefore, attention should be paid to the protection of natural vegetation in the arid oasis area.

The Chinese government has launched policies for ecological protection, such as Grain for Green and ecological red lines. These policies play a key role in promoting the efficient use of land resources and improving oasis landscape sustainability in arid regions in Northwest China, especially in the Qira oasis. However, as agricultural expansion leads to increased income, it is difficult to balance economic development and ecological protection. Currently, the land use policy in the Qira oasis is still directed at wasteland reclamation, and policies focused on oasis diversity, oasis ecological safety, and land and water management are lacking. Therefore, future studies should focus on agricultural oasis expansion and its ecological effect on oasis landscape stability and sustainability.

\section{Conclusions}

In this study, the Qira oasis on the southern margin of the Tarim Basin, Northwest China was selected as a study area to examine the spatiotemporal change of agricultural oasis and determine its influence on oasis landscape pattern based on TM, ETM+, and GF-1 images. Furthermore, the driving force of oasis landscape pattern under agricultural oasis expansion was analyzed by using hydrometeorological and socioeconomic data.

The results show that the agricultural oasis in the Qira oasis has increased rapidly, with annual change rates of $-0.3 \%, 1.6 \%, 3.7 \%$, and $1.5 \%$ in 1970-1990, 1990-2000, 2000-2013, and 2013-2016, 
respectively. The agricultural land has increased from $91.10 \mathrm{~km}^{2}$ in 1970 to $105.04 \mathrm{~km}^{2}$ in 2016 . The percentage of farmland area increased by $15.3 \%$ between 1970 and 2016 . The natural vegetation is decreasing owing to the reclamation of the desert-oasis ecotone. The oasis landscape change pattern is mainly affected by agricultural expansion under water-saving technological utilization, land use policy, and demand for regional economic development. The expansion of agricultural oasis is alarming due to human overexploitation.

Understanding oasis landscape change is essential for its sustainable management. The expansion of agricultural irrigation in the oasis has dramatically affected the landscape stability and ecological sustainability. Therefore, effective solutions (e.g., government policies directed at controlling the overexpansion of agricultural oasis) should be proposed. Future studies should focus on the ecological effect of and water shortage created by agricultural oasis expansion.

Author Contributions: All authors contributed to the design and writing of this manuscript. Y.L. and J.X. carried out the data analysis and prepared the first draft of the manuscript; D.G., J.L. and G.L. are the graduate advisors of Yi Liu and contributed an overall internal review; H.S. and Z.Z. provided important advice on the manuscript.

Acknowledgments: This work was financially supported by the National Natural Science Foundation of China (41601595, 41471031), the "Western Light" program of the Chinese Academy of Science (2017-XBQNXZ-B-016), the State Key Laboratory of Desert and Oasis Ecology, Xinjiang Institute of Ecology and Geography, Chinese Academy of Sciences (1100002394), the Task 2 of the Key Service Project 5 for the Characteristic Institute of CAS (TSS-2015-014-FW-5-3), and the Project of Science and Technology Service Network Initiative of CAS (KFJ-SW-STS-176).

Conflicts of Interest: The authors declare no conflict of interest.

\section{References}

1. Verburg, P.H.; Soepboer, W.; Veldkamp, A.; Limpiada, R.; Espaldon, V.; Mastura, S.A. Modeling the spatial dynamics of regional land use: The CLUE-S model. Environ. Manag. 2002, 30, 391-405. [CrossRef] [PubMed]

2. Bruelheide, H.; Jandt, U.; Gries, D.; Thomas, F.M.; Foetzki, A.; Buerkert, A.; Wang, G.; Zhang, X.M.; Runge, M. Vegetation changes in a river oasis on the southern rim of the Taklamakan Desert in China between 1956 and 2000. Phytocoenologia 2003, 33, 801-818. [CrossRef]

3. Nagendra, H.; Munroe, D.K.; Southworth, J. From pattern to process: Land-scape fragmentation and the analysis of land use/land cover change. Agric. Ecosyst. Environ. 2004, 101, 111-115. [CrossRef]

4. Turner, B.L. The sustainability principle in global agendas: Implications for understanding land-use/cover change. Geogr. J. 1997, 163, 133-140.

5. Lambin, E.F.; Geist, H.J. Land-Use and Land-Cover Change: Local Processes and Global Impacts; The IGBP Series; Springer: Berlin, Germany, 2006.

6. Jia, B.Q.; Zhang, Z.Q.; Ci, L.J.; Ren, Y.P.; Pan, B.R.; Zhang, Z. Oasis land-use dynamics and its influence on the oasis environment in Xinjiang, China. J. Arid Environ. 2004, 56, 11-26. [CrossRef]

7. Amuti, T.; Luo, G. Analysis of land cover change and its driving forces in a esert oasis landscape of Xinjiang, northwest China. Solid Earth 2014, 5, 1071-1085. [CrossRef]

8. Xie, Y.C.; Gong, J.; Sun, P.; Gou, X.H. Oasis dynamics change and its influence on landscape pattern on Jinta oasis in arid China from 1963a to 2010a: Integration of multi-source satellite images. Int. J. Appl. Earth Obs. 2014, 33, 181-191. [CrossRef]

9. Liu, J.Y.; Zhang, Z.X.; Xu, X.L.; Kuang, W.H.; Zhou, W.C.; Zhang, S.W.; Li, R.D.; Yan, C.Z.; Luo, G.P.; Feng, Y.X.; et al. Sustainable land-use patterns forarid lands: A case study in the northern slope areas of the Tianshan Mountains. J. Geogr. Sci. 2010, 20, 510-524.

10. Song, W.; Zhang, Y. Expansion of agricultural oasis in the Heihe River Basin of China: Patterns, reasons and policy implications. Phys. Chem. Earth Parts A/B/C 2015, 89-90, 46-55. [CrossRef]

11. Gui, D.; Xue, J.; Liu, Y.; Lei, J.; Zeng, F. Should oasification be ignored when examining desertification in Northwest China? Solid Earth Discuss. 2017, under review. [CrossRef]

12. Han, D.L.; Meng, X.Y. Recent Progress of Research on Oasis in China. Chin. Geogr. Sci. 1999, 9, $199-205$. [CrossRef]

13. Cheng, W.; Zhou, C.; Liu, H.; Zhang, Y.; Jiang, Y.; Zhang, Y.; Yao, Y. The oasis expansion and eco-environment change over the last 50 years in Manas River Valley, Xinjiang. Sci. China Ser. D 2006, 49, 163-175. [CrossRef] 
14. Xue, J.; Gui, D.W.; Zhao, Y.; Lei, J.Q.; Zeng, F.J.; Feng, X.L.; Mao, D.L.; Shareef, M. A decision-making framework to model environmental flow in oasis areas using Bayesian networks. J. Hydrol. 2016, 540, 1209-1222. [CrossRef]

15. Guo, M.; Yu, W.B.; Ma, M.G.; Li, X. Study on the oasis landscape fragmentation in northwestern China by using remote sensing data and GIS: A case study of Jinta oasis. Environ. Geol. 2008, 54, 629-636.

16. Bai, J.; Chen, X.; Li, L.; Luo, G.; Yu, Q. Quantifying the contributions of agricultural oasis expansion, management practices and climate change to net primary production and evapotranspiration in croplands in arid northwest China. J. Arid Environ. 2014, 100, 31-41. [CrossRef]

17. Ling, H.B.; Xu, H.L.; Fu, J.Y.; Fan, Z.L.; Xu, X.W. Suitable oasis scale in a typical continental river basin in an arid region of China: A case study of the Manas River Basin. Quat. Int. 2013, 286, 116-125. [CrossRef]

18. Zhang, H.; Wu, H.W.; Zheng, Q.H.; Yu, Y.H. A preliminary study of oasis evolution in the Tarim Basin, Xinjiang, China. J. Arid Environ. 2003, 55, 545-553.

19. Zhou, D.; Wang, X.; Shi, M. Human Driving Forces of Oasis Expansion in Northwestern China during the Last Decade-A Case Study of the Heihe River Basin. Land Degrad. Dev. 2017, 28, 412-420. [CrossRef]

20. Wang, Y.; Gao, J.X.; Wang, J.S.; Qiu, J. Value assessment of ecosystem services in nature reserves in Ningxia, China: A response to ecological restoration. PLoS ONE 2014, 9, e89174. [CrossRef] [PubMed]

21. Su, Y.Z.; Zhao, W.Z.; Su, P.X.; Zhang, Z.H.; Wang, T.; Ram, R. Ecological effects of desertification control and desertified land reclamation in an oasis-desert ecotone in an and region: A case study in Hexi Corridor, northwest China. Ecol. Eng. 2007, 29, 117-124. [CrossRef]

22. Zhang, X.F.; Zhang, L.H.; He, C.S.; Li, J.L.; Jiang, Y.W.; Ma, L.B. Quantifying the impacts of land use/land cover change on groundwater depletion in Northwestern China-A case study of the Dunhuang oasis. Agric. Water Manag. 2014, 146, 270-279. [CrossRef]

23. Siebert, S.; Nagieb, M.; Buerkert, A. Climate and irrigation water use of a mountain oasis in northern Oman. Agric. Water Manag. 2007, 89, 1-14. [CrossRef]

24. Xue, J.; Gui, D.W.; Lei, J.Q.; Zeng, F.J.; Mao, D.L.; Zhang, Z.W. Model development of a participatory Bayesian network for coupling ecosystem services into integrated water resources management. J. Hydrol. 2017, 554, 50-65. [CrossRef]

25. Xue, J.; Gui, D.W.; Lei, J.Q.; Zeng, F.J.; Mao, D.L. A hybrid Bayesian network approach for trade-offs between environmental flows and agricultural water using dynamic discretization. Adv. Water Resour. 2017, 110, 445-458. [CrossRef]

26. Xu, L.; Mu, G.; Ren, X.; Wan, D.; He, J.; Lin, Y. Oasis microclimate effect on the dust deposition in Cele oasis at southern Tarim Basin, China. Arab. J. Geosci. 2016, 9, 1-7.

27. Mao, D.L.; Lei, J.Q.; Li, S.Y. Characteristics of meteorological factors over different landscape types during dust storm events in Cele, Xinjiang, China. J. Meteorol. Res. 2014, 28, 576-591. [CrossRef]

28. Lin, Y.; Mu, G.; Xu, L.; Zhao, X. The origin of bimodal grain-size distribution for aeolian deposits. Aeolian Res. 2016, 20, 80-88. [CrossRef]

29. Liu, J.Y.; Kuang, W.H.; Zhang, Z.X.; Xu, X.L.; Qin, Y.W.; Ning, J.; Zhou, W.C.; Zhang, S.W.; Li, R.D.; Yan, C.Z.; et al. Spatiotemporal characteristics, patterns, and causes of land-use changes in China since the late 1980s. J. Geogr. Sci. 2014, 24, 195-210. [CrossRef]

30. Liu, J.Y.; Liu, M.L.; Tian, H.Q.; Zhuang, D.F.; Zhang, Z.X.; Zhang, W.; Tang, X.M.; Deng, X.Z. Spatial and temporal patterns of China's cropland during 1990-2000: An analysis based on Landsat TM data. Remote Sens. Environ. 2005, 98, 442-456. [CrossRef]

31. Pontius, J.R.G.; Shusas, E.; McEachern, M. Detecting important categoricalland changes while accounting for persistence. Agric. Ecosyst. Environ. 2004, 101, 251-268. [CrossRef]

32. Zhou, D.C.; Luo, G.P.; Lu, L. Processes and trends of the land use change in Aksu watershed in the central Asia from 1960 to 2008. J. Arid Land 2010, 2, 157-166.

33. Hotan Water Resources Planning. 2013; Xinjiang Tarim River Basin Management Bureau. Available online: http:/ / www.tahe.gov.cn (accessed on 4 June 2018).

34. Shen, Y.; Lein, H.; Xi, C. Water conflicts in Hetian District, Xinjiang, during the Republic of China period. Water Hist. 2016, 8, 77-94.

35. Mao, D.; Lei, J.; Zhao, Y.; Zhao, J.; Zeng, F.; Xue, J. Effects of variability in landscape types on the microclimate across a desert-oasis region on the southern margins of the Tarim Basin, China. Arid Land Res. Manag. 2016, 30, 89-104. [CrossRef] 
36. Li, X.Y.; Xiao, D.N.; He, X.Y.; Chen, W.; Song, D.M. Dynamics of typical agricultural landscape and its relationship with water resource in inland Shiyang River watershed, Gansu Province, northwest China. Environ. Monit. Assess. 2006, 123, 199-217.

37. Yu, D.S.; Wu, S.X.; Nan, J. Spatial patterns and driving forces of land use change in China during the early 21st century. J. Geogr. Sci. 2010, 20, 483-494.

38. Fu, L.; Zhang, L.H.; He, C.S. Analysis of agricultural land use change in the middle reach of the Heihe River Basin, Northwest China. Int. J. Environ. Res. Public Health 2014, 11, 2698-2712. [CrossRef] [PubMed]

39. Zhou, S.; Huang, Y.F.; Yu, B.F.; Wang, G.Q. Effects of human activities on the eco-environment in the middle Heihe River Basin based on extended environmental Kuznets curve model. Ecol. Eng. 2015, 76, 14-26. [CrossRef]

(C) 2018 by the authors. Licensee MDPI, Basel, Switzerland. This article is an open access article distributed under the terms and conditions of the Creative Commons Attribution (CC BY) license (http:// creativecommons.org/licenses/by/4.0/). 